\title{
A Longitudinal Evaluation of a Teacher Education Project: CLAC 20 Years Later
}

\section{Uma avaliação longituginal de um projeto de formação de professores: CLAC 20 anos depois}

Sonia Zyngier*

*Universidade Federal do Rio de Janeiro (UFRJ), Rio de Janeiro, Rio de Janeiro / Brasil sonia.zyngier@gmail.com

https://orcid.org/0000-0002-6355-6407

Gabriela Marques-Schäfer**

**Universidade do Estado do Rio de Janeiro (UERJ), Rio de Janeiro, Rio de Janeiro /

Brasil

gabrielamarques@yahoo.com

https://orcid.org/0000-0001-5574-2333

Danielle de Almeida Menezes***

*** Universidade Federal do Rio de Janeiro (UFRJ), Rio de Janeiro, Rio de Janeiro /

Brasil

danielle.menezes1981@gmail.com

https://orcid.org/0000-0001-7404-4928

Alessandra Mitie Spallanzani****

****Centro Federal de Educação Tecnológica Celso Suckow da Fonseca (CEFET),

Nova Friburgo, Rio de Janeiro / Brasil

alemitie@gmail.com

https://orcid.org/0000-0002-3117-4068

RESUMO: Atualmente, o envolvimento em programas de extensão universitária é obrigatório para alunos de graduação na área de Ciências Humanas. No entanto, antes de 2015, os esforços nessa área eram bastante escassos e tendiam a se concentrar em serviços e consultoria. Poucos eram os projetos como o CLAC (Cursos de Línguas Abertos à Comunidade) que visavam preparar os professores para as realidades da sala de aula por meio de uma experiência prática. A fim de examinar a influência que este projeto pioneiro pode ter sobre a vida acadêmica, profissional e pessoal dos participantes, este artigo relata um estudo longitudinal com 60 participantes. Suas respostas a um questionário on-line indicam que o projeto atingiu seus objetivos em termos de promoção de pensamento crítico, autonomia e preparação de profissionais 
bem qualificados. Essa avaliação evidencia que esse projeto pioneiro é um modelo a ser replicado.

PALAVRAS CHAVE: formação de professores, programa de formação de professores, extensão universitária, autonomia e avaliação longitudinal

\begin{abstract}
Today, engaging in university extension programs is mandatory for undergraduate students in Humanities. However, before 2015, efforts in this area were rather scant and tended to concentrate on services and consultancy. Few were the projects, like CLAC (Language Courses for the Community), that aimed at preparing teachers for the realities of the classroom by means of a hands-on experience. To examine the influence this pioneer project may have on the academic, professional, and personal life of the participants, this paper reports a longitudinal study with 60 participants. Their answers to an online questionnaire indicate that the project reached its objectives in terms of promoting critical thinking and autonomy, and preparing well-qualified professionals. This assessment shows that this pioneering project is a model that should be replicated.
\end{abstract}

KEYWORDS: teacher education, teacher pre-service program, university extension, autonomy, longitudinal assessment

\title{
1. Introduction
}

For decades, teacher education in Brazil was based on a system widely known as " $3+1$ " (see MENEZES, 2015). This formula stands for the fact that undergraduates study languages, literature, and linguistics during their first three years and the pedagogical subjects are only offered in their senior year. This model erroneously assumed that one year was enough to prepare students for the teaching practice (MENEZES, 2015).

Moreover, this model promotes little contact with educational settings, thus thwarting optimal results. At the turn of this century, when new National Curricular Guidelines for Teacher Education Courses (BRASIL, 2002) were published, the new objective was to offer an innovative frame for teacher education in Brazil, one which articulated content and pedagogical disciplines more clearly. In 2015, another version of the Curricular Guidelines (BRASIL, 2015) was produced. The document reinforced the importance of professional training by means of a close partnership between universities and school settings. Thus, official initiatives that draw attention to the need to prepare teachers before they graduate are very recent and have not yet been widely implemented. Action is still limited to a few educators who see the need for this articulation between learning and practice. Therefore, despite the efforts from the Government to prepare 
pre-service teachers for the realities of the classroom, the results have been neither satisfactory nor noticeable so far. In addition, most of these initiatives have been rather unsuccessful in preparing pre-service teachers to work in a critical manner (KINCHELOE, 1997; PÉREZ GÓMEZ, 1992; CELANI, 1984).

Before the 2015 publication, and aware of this need, the School of Letters of the Federal University of Rio de Janeiro (henceforth FL-UFRJ) launched an Extension program in 1998, seeking to promote pre-service teachers' professional and scientific development. These activities involved teaching foreign languages to individuals from all walks of life in Rio, including those from a slum area near the University.

In this paper, we investigate the impact of CLAC (Cursos de Línguas Abertos à Comunidade/Language Courses for the Community) on pre-service teachers' academic, professional, and personal life 20 years after its implementation. In a country like Brazil, where graduating as a teacher is far from the students' professional preference (see also the study conducted by SEMESP in 2017), ${ }^{1}$ it is important to check what influence such actions may have on the students' general performance. In this light, we carried out the longitudinal study reported here. To reach the participants, we looked up their emails and accessed other social media contacts. Once contacted, each participant was asked to answer to a questionnaire. In the following sections we detail the study. ${ }^{2}$

\section{The context and the CLAC Project}

An initiative of FL-UFRJ, the CLAC Project was designed in 1987. However, as the University interrupted its sponsorship and stopped providing scholarships to students, the project came to an end in 1996. Two years later, a newly-elected Director for Cultural Affairs decided to give a new form and structure to the project, expand its aims, and make it self-supporting. Students were expected to contribute with a very small fee (around US\$ 40.00) per semester to finance scholarships, textbooks and

\footnotetext{
${ }^{1}$ General information about the study can be found at: https://ultimosegundo.ig.com. br/educacao/2017-11-08/cursos-de-licenciatura.html. Retrieved on: January 21, 2019.

${ }^{2}$ We would like to thank the participants who, after 20 years away from the Project, contributed with their responses to our questionnaire. Without them, this study would not have been possible.
} 
reference books for the teachers, tape-recorders (multimedia gadgets were not available at that time), and other equipment. Each class of 25 students offered at least 5 gratuities to those who could not afford the fee. In addition, after two semesters, when the project had enough funds to offer more scholarships, it was extended to two different slum areas. For these students, the courses were free of charge.

Under this new design, the courses were open to anyone who would come to the University for language classes tutored by undergraduates from the FL-UFRJ, who were supervised by the Faculty members. The courses consisted of 6 hours per week for four semesters. Students would come twice or three times to the University for these classes (in the slum areas, the tutors would teach in loco). They were mostly teachers or students from the campus, although, as mentioned above, the courses were open to any resident of Rio de Janeiro. Due to the success of the courses, in 1999 other more compact versions were opened, consisting of 4 hours on Saturdays (also for four semesters). The 6-hour and the 4-hour per week courses were carried out in parallel.

The general objective of this pioneer project was to strengthen the links between the university and the community, as the 2015 federal government guidelines would later define. It promoted the acquisition of different languages at the same time that it offered an environment for the development of pre-service teachers and researchers (see also ZYNGIER; LIBERALI 2001a; ZYNGIER; LIBERALI, 2001b; MARQUES et al., 2005). The aim was to prepare teachers who would be able to: 1) observe and analyze problems in their own practices; 2) be in a position to effect the necessary changes; 3 ) be in tune with both general and specific contexts; 4) know how to choose and develop educational materials; 5) evaluate students' specific needs; 6) criticize the social, cultural, and political aspects involved in their teaching practices; 7) develop autonomy and the skill of questioning; 8 ) become aware of their social roles as agents of social mobility. In terms of the pre-service teachers' development as researchers, the Project sought to promote a place where both faculty and undergraduates could carry out research projects jointly, report the results at conferences, and publish their papers in peer-reviewed periodicals.

To join the project, undergraduates had to undergo a selection process and were later assigned supervisors with whom they met weekly. Besides the staff, these supervisors could also be postgraduate students interested 
in developing research in the area. Pre-service teachers were asked to write a diary in which they would keep track of problems and events which were then discussed at the weekly meetings with the supervisor (for further details, see LIBERALI; ZYNGIER, 2000). They were also assigned a bibliography that would inform the meetings.

The supervisions generally contemplated issues of language structure, function, and context of use, including the following items, among others: 1) acquiring means of observing, understanding, and transforming classes in a substantiated way; 2) identifying views of language teaching and learning that underlie classroom actions and events; 3) realizing the social and political implications of actions taken; 4) noticing the needs of different contexts; 5) developing students' confidence and communicative skills; 6) assessing books, activities, extra materials, tests, etc.; 7) deciding on when to use students' first language in class. Interest in discussing topics related to everyday practice, to the way in which textbooks dealt with minorities, with issues of racism, sexism, and poverty, would also be raised. Thus, it was possible to develop parameters for self-analysis and transformation.

\section{Theoretical pillars}

To understand the pillars on which the project stood, critical teaching, autonomy, and the aims of university extension must be considered, as discussed in the following sections.

\subsection{Critical teaching}

The main aim of critical teaching is to empower pre-service teachers so that they can reflect on their actions and change them. According to Kincheloe (1997), this way of understanding teaching practice defies crystallized structures and traditions to which teachers may be used to and challenges them to create new modes of teaching and thinking. Critical or reflective teaching (FREIRE, 1970; SMYTH, 1992) can be obtained by means of four different actions:

- Describing, or textually rendering concrete teaching events in order to arrive at an account of practice;

- Informing or disclosing the principles and theories of teaching and learning that underlie actions in the classroom; 
- Confronting or the questioning of the actions, principles, and theories that take place in the teaching environment, situating them in a broader cultural, social, and political context;

- Reconstructing or reorganizing one's own action as a result of the process of describing, informing, and confronting.

These actions allow pre-service teachers to analyze and review the social and historical forces involved in their decisions. Up to a certain extent, reflective teachers turn into researchers of classroom events (LIBERALI, 1999) and contextualize knowledge socially and historically. According to Kincheloe (1997), this is possible because teachers can then develop and use knowledge in context and during interaction.

\subsection{Autonomy}

When it was redesigned in the late 1990s, one of the main goals of the CLAC Project was to foster both teachers' and students' autonomy. Based on the tenets of Critical Pedagogy (FREIRE, 1996; GIROUX, 1997), the Project conceived autonomy as more than just taking responsibility for one's own teaching and/or learning, which is a widely known definition, given by Holec (1981), or, as Little (1981) puts it, the capacity for critical reflection, detachment, independent action, and decision-making. Going beyond these limits, the Project saw autonomy as getting involved with the social environment. According to Freire (1996), autonomous teachers direct their practice to the students' interests. They are expected to take into account different variables, such as their own views of what works and what does not, their students' background and interests, the learning environment, as well as the curriculum proposed by the institution. By means of hands-on teaching experience, the CLAC Project aimed to offer participants the opportunity to develop professionally, articulating theory and practice, at the same time that they would see themselves as acting upon and impacting their environment.

Autonomy may be developed in different ways, depending on the learners' needs and the contexts they belong to (NICOLAIDES; FERNANDES, 2008). Such rationale is based on presuppositions posed by Freire (1996), who argues that (1) Reflection supports action and our actions influence society; (2) Teaching is not knowledge transmission - it is an exchange between teachers and students; and (3) Educators should be seen by learners as promoters of free thinking. These principles were planned 
as the focus of the weekly supervision sessions, during which participants would be expected to share their teaching experiences, reflect upon their attitudes, elaborate teaching materials, and make decisions resulting from the assigned readings. These sessions were based on the assumption that autonomy in education requires hard work before it can be achieved.

\subsection{University Extension}

Extension programs within the public institutions of higher education play an essential role when it comes to social and scientific development. First, observed in England in the mid-nineteenth century (PAULA, 2013), and still in effect in Brazil, as set forth in legal documents, such as Article 207 of the Constitution of the Federative Republic of Brazil (BRASIL, 1988) and the Brazilian Educational Laws and Guidelines - LDB 9394/96 (BRASIL, 1997), University Extension programs are not only highly encouraged, but they are expected to be part of the students' curriculum. According to the National Education Plan (2014-2024), passed by the Brazilian Government under Law \#13.005/2014 (BRASIL, 2014), 10\% of the hour load of graduate level courses must be fulfilled by means of participating in University Extension programs and projects. This determination is recent and, even though the notion that teaching, research, and extension cannot be dissociated was known 30 years ago, the teaching and research were still considered the main areas of action in Brazilian universities. However, data from nearly 400 papers presented in both 2000 and 2001 Extension Conferences held by UFRJ revealed how the three areas could and should always be combined, as the National Plan for University Extension would recommend years later (see also BRASIL, 2009). Hence, in line with this document, UFRJ has actually been developing University Extension projects since the 1990s, including the CLAC Project.

In terms of University Extension programs, their links between university and society can be represented not by a two-way, but by a multipleway metaphor, providing interactions of the most diverse nature. As a constant, the university focuses on the social and political reality in which it is placed, identifying problems and offering solutions that will benefit the community in general (FORPROEXT, 2012). Due to its flexibility, University Extension activities can go beyond the borders of departments and other university units, bringing together academic and popular knowledge (FREIRE, 1983). 
According to the UFRJ Statutes, there are three different and broad areas where Extension programs may act (UNIVERSIDADE, 2018): continuing studies (courses, etc.), consultancy to companies or assistance to deprived communities, hospitals, etc., and cultural events (festivals, conferences, exhibitions, etc.). In this light, the CLAC Project stands as an example of academic work aligned with these areas as well as with the $10 \%$ of the undergraduate hour load which characterizes an integrative approach. The project involves university students as pre-service teachers; it works towards improving the conditions of those who join the Project; the supervisors are lecturers and postgraduate students; and it offers a service (language classes) at a very low cost or for free so that individuals may have a chance to increase the span of their cultural horizon. This integration reinforces the metaphor of a multiple-way road and simultaneously shows how far-reaching the possibilities of University Extension actions can be.

\section{The Study}

For 20 years, the CLAC Project has been offering courses on the following languages: English, Spanish, German, French, Italian, Japanese, Portuguese (as a second language and for academic purposes), and Hebrew. To find out if the project had any impact on the lives of the first preservice teachers after 20 years, an online questionnaire with 13 questions in Portuguese (the participants' first language) was elaborated (see Annex), with five multiple choice questions and eight open-ended ones. To reach the participants, a search through the Facebook group to which some of them were affiliated was conducted. Following the links of one and another individual, we managed to contact 60 former pre-service teachers (out of 200) who participated in the project during the period of 1998-2003. We are aware that this number may not be significant enough for a quantitative study, but it can still help us determine what aspects may have been affected. To reach the participants, a link to the questionnaire was sent out to them. ${ }^{3}$

\footnotetext{
${ }^{3}$ We have left the original questionnaire in Portuguese, but the answers have been translated into English by the authors for the purposes of this report.
} 


\subsection{Participants' profile}

All participants were former pre-service teachers. As we considered the distinction regarding sex irrelevant, we did not ask this question. Most of them had been tutors of English (60\%), followed by those of German $(21.6 \%)$, Spanish (10\%), French (6.7\%), and Italian (1.7\%). Pre-service teachers from other languages did not complete the questionnaire. The difference between groups results from the fact that more English courses were offered than the others due to demand. In addition, the respondents were limited to those the researchers managed to contact via email.

Most participants $(73.3 \%)$ contributed to the project for more than two years, whereas $16.7 \%$ from three to four semesters. Only 10\% were part of CLAC for 1 or 2 semesters. This means that their stay in the project was rather long.

Only $15 \%$ of the participants did not continue their studies after receiving their undergraduate degree. Most participants (75\%) felt motivated to pursue further education or another undergraduate degree (4\%), 22\% obtained a specialization degree, $42 \%$ obtained an M.A., $28 \%$ a Ph.D., and 4\% a post-doctorate. When asked if their experience in the project had influenced their decision to carry out postgraduate work, 57\% agreed that it definitely had and $14 \%$ that it had contributed in an indirect way. Therefore, a total of $71 \%$ stated that the project impacted their decision, directly or indirectly. Only 25\% said there had been no influence at all and 4\% did not reply.

As to the teaching profession, most participants $(90 \%)$ continued their work as teachers, whereas 10\% pursued other professions in Brazil ${ }^{4}$ and abroad. Currently, one works at a private business company overseas, while two others have been employed by private companies in Brazil. One of the latter is in the teaching area, where English is taught as a tool for technical courses aimed at the job market.

Table 1 shows how $90 \%$ of the participants that have been working as teachers are distributed:

\footnotetext{
${ }^{4}$ Five participants are civil servants today working in the following locations: Brazilian Court of Auditors (TCU), the Brazilian Institute of Geography and Statistics (IBGE), the Ministry of Foreign Affairs (MRE), the Brazilian Government Agency for Law Enforcement and Prosecution (MPF), and the Brazilian Air Force (FAB - still in the teaching area but specifically acting at a post-vocational training for qualification and English language assessment of air traffic controllers).
} 
TABLE 1 - Current workplaces

\begin{tabular}{|c|c|c|c|c|c|c|c|c|c|c|c|c|c|}
\hline \multicolumn{4}{|c|}{ University } & \multicolumn{4}{|c|}{ Schools } & \multicolumn{4}{|c|}{$\begin{array}{c}\text { Independent language } \\
\text { courses }\end{array}$} & \multirow{2}{*}{\multicolumn{2}{|c|}{ Total }} \\
\hline \multicolumn{2}{|c|}{ In Brazil } & \multicolumn{2}{|c|}{ Abroad } & \multicolumn{2}{|c|}{ Private } & \multicolumn{2}{|c|}{ Public } & \multicolumn{2}{|c|}{ In Brazil } & \multicolumn{2}{|c|}{ Abroad } & & \\
\hline$\#$ & $\%$ & $\#$ & $\%$ & $\#$ & $\%$ & $\#$ & $\%$ & $\#$ & $\%$ & $\#$ & $\%$ & $\#$ & $\%$ \\
\hline 16 & 24.6 & 3 & 4.6 & 16 & 24.6 & 18 & 27.6 & 10 & 15.3 & 2 & 3 & 65 & 100 \\
\hline
\end{tabular}

The total of 65 exceeds the number of 60 participants, as some have been working simultaneously in private and public schools or in schools and independent language courses. Three participants are autonomous teachers in Brazil (1) and abroad (2).

From Table 1, we can notice the breadth and the variety of workplaces. It is worth mentioning that 19 participants are university teachers nowadays, lecturing in Teacher Education Undergraduate Courses.

\subsection{Results}

The results show that the vast majority of respondents attribute a decisive role in their job position to the CLAC Project, as Table 2 indicates:

TABLE 2 - Impact on current job

\begin{tabular}{c|c|c|c|c|c|c|c}
\hline \multicolumn{2}{c|}{ Influence } & \multicolumn{2}{c|}{$\begin{array}{c}\text { Partial } \\
\text { Influence }\end{array}$} & \multicolumn{2}{c}{ No Influence } & \multicolumn{2}{c}{ Total } \\
\hline$\#$ & $\%$ & $\#$ & $\%$ & $\#$ & $\%$ & $\#$ & $\%$ \\
\hline 48 & $80 \%$ & 5 & $8.3 \%$ & 7 & $11.7 \%$ & 60 & $100 \%$ \\
\hline
\end{tabular}

According to Table 2, only 7 respondents answered that the CLAC Project had no impact. The majority $(80 \%)$, however, agrees that it has influenced them, but not all participants have explained how. The ones who did provide an explanation enabled the researchers to think of seven types of influence, as follows:

- Teaching experience $\rightarrow$ Example: "The years at CLAC opened the doors for me to teach Portuguese at the University of Copenhagen";

- Learning offered $\rightarrow$ Example: "The School of Letters only started to make sense for me when I joined CLAC, which taught me a lot of the professionalism I apply today"; 
- Supervision obtained $\rightarrow$ Example: "I had the opportunity to be supervised by a very competent professional";

- Stimulus to autonomy, critical thinking, and/or academic studies/ research $\rightarrow$ Example: "I have learned how to be more autonomous and reflexive upon my pedagogical practice in teaching EFL"; "It was at CLAC that I met people who were part of the REDES [Research and Development in Empirical Studies] project, which helped me a great deal on my research path";

- Teamwork $\rightarrow$ Example: "I was able to (...) share knowledge and materials with colleagues (...) and always propose teamwork, as I was used to doing at CLAC";

- Entrepreneurship and business $\rightarrow$ Example: "I opened my own business in the area";

- Scholarship obtained $\rightarrow$ Example: the DAAD scholarship for a Master's degree may have been due to my experience and academic interest".

Table 4 Shows the frequency of each category:

TABLE 3 -Type of impact

\begin{tabular}{l|c|c}
\hline \multicolumn{1}{c|}{ Categories } & $\#$ & $\%$ \\
\hline Teaching experience & 10 & 30.3 \\
\hline Learning offered & 9 & 27.2 \\
\hline Supervision obtained & 4 & 12.1 \\
\hline Stimulus to autonomy, critical thinking, and/or academic studies/ research & 6 & 18.1 \\
\hline Teamwork & 2 & 6.1 \\
\hline Entrepreneurship and business & 1 & 3.1 \\
\hline Scholarship obtained & 1 & 3.1 \\
\hline TOTAL & 33 & 100 \\
\hline
\end{tabular}

When asked whether the CLAC Project contributed or not to their education as teachers, all participants provided positive responses, which means that $100 \%$ believed it was an effective teacher training experience. Details relating to how the Project was beneficial to them were given by 19 participants. The categories below reflect the areas they seem to consider 
the most influential. It is important to mention that some answers indicated two areas or more:

- Experience $\rightarrow$ Example: "The experience I gathered was essential";

- Knowledge $\rightarrow$ Example: "I could learn a lot";

- Reflection $\rightarrow$ Example: "It was at CLAC where I really learned to teach and reflect upon my classes";

- Professional choice $\rightarrow$ Example: "I was sure it was what I really want to do professionally";

- Research $\rightarrow$ Example: "It taught me how to be a researcher of my own practice".

The frequency of these categories is shown in Table 4:

TABLE 4 - Impact on teacher training experience

\begin{tabular}{l|c|c}
\hline \multicolumn{1}{c|}{ Categories } & $\#$ & $\%$ \\
\hline Experience & 13 & 48.2 \\
\hline Knowledge & 8 & 29.5 \\
\hline Research & 3 & 11.1 \\
\hline Reflection & 2 & 7.5 \\
\hline Professional choice & 1 & 3.7 \\
\hline TOTAL & 27 & 100 \\
\hline
\end{tabular}

Table 4 shows that nearly half of the participants considered "experience" as the most valuable asset they obtained from the CLAC Project, followed by "knowledge". It is interesting to notice that they also mention "research", but that "reflection" and "professional choice" were not considered to be as relevant.

When describing what participants saw as the overall most positive aspect of the Project, the answers opened up a wealth of categories. Still, general experience and teaching practice remained as the most relevant. The categories are as follows:

- General experience and teaching practice $\rightarrow$ Example: "excellent opportunity for undergraduate students to experience what it is to teach while practicing it at the same time"; 
- Pedagogical support/reflective teaching $\rightarrow$ Example: "the meetings to reflect upon the classroom practice and the guidance from the supervisors responsible for the course";

- Teamwork $\rightarrow$ Example: "cooperation is the key word for CLAC. Both pre-service teachers and supervisors were sharing experience, helping to solve problems, creating amazing lessons, trying out different approaches, all for the benefit of the students";

- Preparation for the job market $\rightarrow$ Example: "I left university very prepared for the job market";

- Experience in research and publication $\rightarrow$ Example: "Many other projects were developed, conferences were held, and articles were published coming out of the CLAC environment";

- Events: $\rightarrow$ Example: "The Academic Forum and the Cultural Fair (...) were great learning opportunities";

- Socialization and affect $\rightarrow$ Example: "the project provides socialization between the pre-service teachers themselves, between them and their students, and among professors (coordinators or supervisors), pre-service teachers and other employees of the FL-UFRJ in order to generate professional partnerships in some cases and bonds of friendship in others";

- Preparing classes, didactic material, and evaluation $\rightarrow$ Example: "Encouragement for developing collective products: evaluations, and activities for classes, cultural fairs, enrollment processes, training among other things";

- Attendance/Interaction with the community and fees charged $\rightarrow$ Example: "The community service offered and the value of the course fees";

- Incentive to study and continuing education $\rightarrow$ Examples: "The incentive to study"; "The continuing education";

- Autonomy and sense of responsibility $\rightarrow$ Examples: "Autonomy"; "The responsibility that was delivered to us";

- Structure and quality of the courses $\rightarrow$ Example: "The organization of the project was a model. Teamwork, discipline, punctuality, friendship, challenges, events". 
The frequency in which these categories occur is shown in Table 5:

TABLE 5 - Variety of positive aspects

\begin{tabular}{l|c|c}
\hline \multicolumn{1}{c|}{ Categories } & $\#$ & $\%$ \\
\hline General experience and teaching practice & 28 & 29.4 \\
\hline Pedagogical support/reflective teaching & 21 & 22.1 \\
\hline Teamwork & 11 & 11.6 \\
\hline Preparation for the job market & 7 & 7.3 \\
\hline Experience in research and publication & 4 & 4.2 \\
\hline Events & 4 & 4.2 \\
\hline Socialization and affect & 4 & 4.2 \\
\hline Preparing classes, didactic material, and evaluation & 3 & 3.2 \\
\hline Attendance/Interaction with the community and fees charged & 3 & 3.2 \\
\hline Incentive to study and continuing education & 3 & 3.2 \\
\hline Autonomy and sense of responsibility & 3 & 3.2 \\
\hline Structure and quality of the courses & 2 & 2.1 \\
\hline Nothing else & 95 & 2.1 \\
\hline TOTAL & 300 \\
\hline
\end{tabular}

To check for consistency, participants were also asked to attribute a grade on a scale of 1 (least important) to 5 (most important) for 10 different aspects about the project, based on the categories suggested and described by Spallanzani (2018). The total number of grades (10 items x 60 participants) is 600 . 
TABLE 6 - Grades attributed

\begin{tabular}{l|c|c|c|c|c}
\hline \multicolumn{1}{c}{ Categories } & \multicolumn{4}{c}{ Scale } \\
\cline { 2 - 6 } & 1 & 2 & 3 & 4 & 5 \\
\hline Organizational skills & 0 & 0 & 9 & 12 & 39 \\
\hline Sense of responsibility & 0 & 0 & 4 & 6 & 50 \\
\hline Academic growth & 0 & 0 & 3 & 16 & 41 \\
\hline Interaction with the community & 0 & 0 & 2 & 8 & 50 \\
\hline Social interaction with colleagues, students, and teachers & 0 & 0 & 2 & 9 & 49 \\
\hline Critical capacity & 0 & 0 & 5 & 14 & 41 \\
\hline Autonomy & 0 & 0 & 2 & 5 & 53 \\
\hline Motivation to study & 0 & 0 & 4 & 13 & 43 \\
\hline Stimulus for teaching career & 0 & 0 & 3 & 5 & 52 \\
\hline Motivation for research & 0 & 4 & 16 & 12 & 28 \\
\hline Total out of 600 (\#) & 0 & 4 & 50 & 100 & 446 \\
\hline Total in \% & $0.7 \%$ & $8.3 \%$ & $16.7 \%$ & $74.3 \%$ \\
\hline
\end{tabular}

Table 6 indicates that all the items offered for evaluation received the highest grade, with autonomy and stimulus for teaching career being the top categories. Motivation for research received the lowest grade, although it still remains positive.

In the questionnaire, participants were also asked to think of five adjectives, which, in their opinion, would define the CLAC Project. Only semantically positive adjectives were forwarded. These adjectives were then classified into 13 semantic groups, as described below:

- General appraisal $\rightarrow$ Examples: good; great; excellent; extraordinary; fantastic, worthy; grand; useful, unforgettable; remarkable; meaningful, essential; fundamental; important; pertinent.

- Motivation and pleasure $\rightarrow$ Examples: motivating; encouraging; compelling, enthralling; gratifying; captivating, etc.

- Formative role $\rightarrow$ Examples: academic; educative; enriching; formative, inspiring; transformative, etc.

- Innovative nature $\rightarrow$ Examples: innovative; pioneer; unique; original, etc. 
- Relevance to the community $\rightarrow$ Examples: community; democratic; popular; social; accessible, etc.

- Reliability $\rightarrow$ Examples: reliable; ethical; serious; committed, etc.

- Socialization $\rightarrow$ Examples: bonding; inclusive; amiable; socialisable, etc.

- Challenge $\rightarrow$ Examples: challenging; stimulating, etc.

- Learning environment $\rightarrow$ Examples: happy; nice; fun; active; dynamic; updated, etc.

- Organization $\rightarrow$ Examples: organized; disciplined, etc.

- Critical reflection $\rightarrow$ Examples: critical, reflexive, thought-provoking, etc.

- Results $\rightarrow$ Examples: effective; efficient; productive, etc.

- Scholarships $\rightarrow$ Example: well-paid.

Table 7 shows the frequency of the categories:

TABLE 7 - Semantic groups of adjectives mentioned

\begin{tabular}{l|c|c}
\multicolumn{1}{c|}{ Categories } & $\#$ & $\%$ \\
\hline General appraisal & 60 & 22.9 \\
\hline Motivation and pleasure & 38 & 14.4 \\
\hline Formative role & 36 & 13.6 \\
\hline Innovative nature & 18 & 6.8 \\
\hline Re Relevance to the community & 18 & 6.8 \\
\hline Reliability & 17 & 6.4 \\
\hline Socialization & 16 & 6.0 \\
\hline Challenge & 14 & 5.3 \\
\hline Learning Environment & 17 & 6.4 \\
\hline Organization & 11 & 4.2 \\
\hline Critical reflection & 10 & 3.8 \\
\hline Results & 8 & 3.0 \\
\hline Scholarships & 2 & 0.7 \\
\hline TOTAL & 265 & 100 \\
\hline
\end{tabular}


The wide variety of aspects offered by participants is an evidence that they considered the Project beneficial in many unanticipated ways. Some respondents, however, did not list 'adjectives', but rather nouns, phrases, and adverbs instead (Examples: "reflection"; "pride"; "research"; "socially"; "good purpose for both students and monitors", etc.). As these 13 answers were not adjectives, they were not categorized. However, it is important to mention that they reinforce the positive dimensions of the CLAC Project.

When asked what they would have changed and why, more than half (55\%) replied they would not change anything. Some misunderstood the question $(12 \%)$ and said they were not aware of how the CLAC Project was today. Therefore, they argued that they could not express their opinion. The other suggestions have been arranged in Table 8 as follows:

TABLE 8 - Suggestions for change

\begin{tabular}{l|c|c}
\multicolumn{1}{c|}{ Categories } & $\#$ & $\%$ \\
\hline No/Nothing & 37 & 55 \\
\hline I don't know how it is today & 8 & 12 \\
\hline Distribute time better and share material & 6 & 9 \\
\hline $\begin{array}{l}\text { Offer more supervision, classroom observation, and cooperation } \\
\text { between coordinators and pre-teachers }\end{array}$ & 5 & 7.5 \\
\hline Increase the number of segments and expand the options & 2 & 3 \\
\hline Provide more resources and better classrooms & 2 & 3 \\
\hline Expand to other contexts & 2 & 3 \\
\hline $\begin{array}{l}\text { Improve the quality of the pre-service teacher evaluation forms and } \\
\text { methods of selection }\end{array}$ & 2 & 1.5 \\
\hline Reduce the number of pupils in the classroom & 1 & 1.5 \\
\hline Carry out more research & 1 & 1.5 \\
\hline Avoid local politics & 67 & 100 \\
\hline TOTAL & & \\
\hline
\end{tabular}

These results show that after 20 years, these former pre-service teachers still believe the CLAC Project does not need to be changed, as it has been of benefit in many different ways. 


\subsection{Corpus analysis}

To provide further data to investigate the assessment more deeply, we looked at how participants worded their justifications. In this sense, we opted for a computational approach that would see through their answers. To carry out this corpus analysis, we digitised all open-ended questions, collected them in one single file, and used AntConc for Windows as a software. The overall corpus contained 6,960 tokens and 1,517 types with a $21.79 \%$ ratio (low). This means that there has not been a great vocabulary variation in the responses, implying a high degree of agreement between the participants. In other words, they tended to say the same things in the same way, although they answered individually and did not have contact with each other.

Our first step in terms of looking at the digitized responses by means of a software was to obtain a word-list. We drew the cutoff line at the frequency of 20 and examined both function and content words that drew our attention. These were, of course, in Portuguese, but we opted for translating them for the sake of our readership. Among the most frequent words (both function and content words) we considered were:

TABLE 9 - Most frequent words

\begin{tabular}{c|c|l}
\hline Item & Frequency & \multicolumn{1}{|c}{ Word } \\
\hline 1 & 61 & As (used as "como") \\
\hline 2 & 61 & Me ("me") \\
\hline 3 & 56 & No ("não") \\
\hline 4 & 54 & My ("minha") \\
\hline 5 & 44 & Was ("foi") \\
\hline 6 & 39 & (I) ("eu") \\
\hline 7 & 37 & Very (as the intensifier "muito") \\
\hline 8 & 34 & Class ("aula") \\
\hline 9 & 32 & More (as the intensifier "mais") \\
\hline 10 & 29 & Professional ("profissional”) \\
\hline 11 & 28 & Today ("hoje") \\
\hline 12 & 26 & Classroom ("sala") \\
\hline 13 & 25 & Students ("alunos") \\
\hline 14 & 25 & Experience ("experiência") \\
\hline 15 & 25 & Pre-service teachers ("monitores") \\
\hline
\end{tabular}




\begin{tabular}{l|l|l}
\hline 16 & 22 & Teachers ("professores") \\
\hline 17 & 22 & To be ("ser") \\
\hline 18 & 21 & Opportunity ("oportunidade") \\
\hline 19 & 20 & Study ("formação") \\
\hline 20 & 20 & My ("meu") \\
\hline
\end{tabular}

As the number of participants was rather small, we decided to use a concordancer to see how some of these more frequent words appeared in their context of use. Due to space restrictions, we limit our analysis to a few items. Our objective is to look at the aura of meaning these words generate and to check whether they sustain or challenge the results obtained with the categorization. Here are the words:

- AS: mostly used in the pattern AS+PROFESSION: out of 61 repetitions, 24 are AS+TEACHER, STUDENT, RESEARCHER, etc. This choice stresses the fact that participants were quite aware of the model of the professional involved;

- ME: The choice of this pronoun renders the discourse more personal and reveals what kind of impact the project had on the participant. In 38 instances out of $61, \mathrm{CLAC}$ is the subject $(\mathrm{CLAC}+\mathrm{VERB}+\mathrm{ME})$, the verbs being in the semantic field of open (2), help (3), deepen (3), give (6), enchant (3), teach (3), make (4), give and stimulate (4), remind (3), allow (4), become (3). These verbs that come in the company of the personal pronoun create a positive aura;

- NO: Out of 56 instances, 13 refer to lack of awareness of how the CLAC Project is today (see Section 4.2), and 11 refer to changes. One laments not having profitted as he or she could have, another one does not teach languages any longer, one never doubted (s)he was a good teacher, another one never doubted the course he/she wanted to take. Basically, there are no negative evaluations of the CLAC Project per se. If anything, participants confess they are rather distant from it today but would not change anything, which reinforces the results described above;

- MY (feminine "Minha"): Out of 54 instances, career (7), experience (6), development, trajectory ("formação" 11), practice (7), professional and academic life (8), life in general (2), time (4). The concordancing indicates that the personal experience is geared towards their work as professionals. But they also extend the experience to their life in general 
and place it in the perspective of time. In sum, the words "ME", "MY/ MINE" (feminine/masculine), and "I" (see item 6 below) show that participants presented a personal evaluation of the project;

- WAS: Out of 44 instances, 12 form the pattern Was+ADJECTIVE (fundamental, essential, decisive, positive, etc.), whereas 8 come in the pattern WAS + POSITIVE NOUN (privilege, important moment, perfect solution, best experience). The frequent use of this verb in both these patterns shows that they establish an evaluation of what was before and what was after joining the CLAC Project. They look back and express a positive evaluation;

- I: Out of 39 instances, 14 express the idea of overcoming something (managed, could). Some say that they had financial difficulties before joining the CLAC Project, and one even confesses he/she would have left the university (3) but for the project ("CLAC was the only opportunity I had to start my professional life. I had financial responsibilities"). The concordancing of "I" shows that participants had difficulties of different sorts before joining the project and that the experience helped them overcome them;

- EXPERIENCE: The fact that this word is one of the most frequent ones reinforces the results obtained with the categorization (see Tables 3 and 4), where is it one of the most important aspects. Students see CLAC not as a duty but as a hands-on opportunity that differs from other university projects.

\section{Discussion}

The first aspect that draws our attention when comparing content and corpus analysis (Sections 4.2 and 4.3) is the great impact the CLAC Project had on the participants' personal and professional growth. The high frequency of $1^{\text {st }}$ person pronouns ("me", "my/mine", "I") and the co-text around them (such as: "teach me", "made me", "my career", "my development", "my experience", "I got", "I can", etc.) are in line with the most frequent categories found for the open questions: "Teaching experience" (Table 3); "Experience" (Table 4); "General experience and teaching practice" (Table 5); "Autonomy" and "Stimulus for Teaching career" (Table 6 ). This outcome reinforces the positive view participants expressed about CLAC in all the questions, which leads us to believe that, for 
most 1998-2003 pre-service teachers, being part of the CLAC Project was a turning point in their lives, probably decisive in many of the professional choices they had to make later on in life. Other frequent words listed in Section 4.3 ("professional"; "today"; "opportunity") seem to confirm this understanding.

The data also showed us that the pillars which sustained the project (Critical Thinking; Autonomy; University Extension) were implied in the answers participants provided. We noticed that many of the categories we found for different questions, though not always the most frequent ones, directly illustrated or pressupposed such pillars (see, for instance, in Table 3, the category "Stimulus to autonomy, critical thinking and/or academic studies/research"). As shown in Table 4, "Research / Reflection" evokes Critical Thinking. In Table 5, "Pedagogical support / Reflective teaching", "Autonomy and sense of responsibility", and "Attendance / Relation with the community and course fees" make direct reference, in this order, to Critical Thinking; Autonomy and University Extension. The categories "Autonomy" and "Sense of responsibility", in Table 6, are in line with our understanding of Autonomy, whereas "Interaction with the community" and "Critical capacity" clearly relate to Extension and Critical reflection. Finally, in Table 8, "Relevance to the community" provides grounds for the reason why we have University Extension, while "Critical Reflection" relates again to Critical Thinking.

It is important to point out that, despite the fact that we registered the six least frequent categories occurring in Tables 3 through 7 , none of them refer to negative aspects, but rather to a low frequency of positive comments concerning the CLAC Project. As for Table 8, although most participants informed they would not change anything in the project's structure, their answers suggest better time distribution and material sharing, as well as the desire for more supervision and cooperation between coordinators and preservice teachers, topics not directly related to the three pillars mentioned above.

Corpus analysis showed that the justifications the participants gave were very similar in the way they were worded. They tended to agree in their evaluation. These findings seem to reveal that the philosophical and theoretical aims of the CLAC Project were successfully grasped by these preservice teachers. As pointed out, the CLAC Project managed to demonstrate the need for professional and academic improvement as the participants 
engaged in further courses. This indicates that they saw studying as a continuing process which does not end when the B.A. has been obtained.

\section{Concluding remarks}

This study aimed to analyze the pre-service teachers' assessment of the CLAC Project after 20 years. Despite the fact that the results were quite positive, what we were genuinely interested in was knowing what paths our former students had taken, and to achieve this, we sought to ask questions and make analyses that were as imparital as possible.

Our aim with this report is to share this experience with other readers and not to promote a model. Each environment presents its own challenges, and we are aware that adaptations will necessarily need to be made. Nevertheless, our findings indicate that if other institutions implement University Extension Programs that target teacher education along these lines, they may well turn out to be as successful as the pioneer work reported here. The CLAC Project raised such an interest that most participants remained in it for over 2 semesters. They were truly involved and their evaluation revealed its positive aspects in a number of ways. In addition, most respondents continued their studies and stated they had been influenced by the Project. Thus, the bridge between practice and research has been strengthened. An illustration of its contribution to the participants' professional insertion is the fact that $11.4 \%$ work as lecturers in universities and $51.2 \%$ teach in private and public schools despite the dire conditions found in some of these institutions. The CLAC Project seems to have given them enough support to persist and to know how to deal with the adversities in the teaching profession.

Another very important dimension was the development of the notion that one should commit to the well-being of the community. In this sense, the social relevance of the CLAC Project became quite clear. This aspect was mentioned by many of the participants even after 20 years.

Finally, we would like to reinforce the need for longitudinal studies when appraising University Extension projects. This kind of research provides a reliable and perhaps more neutral - that is, as much as possible - perspective of the project being appraised. Further studies could involve an interview with the participants who mentioned the areas that needed improvement (see also Table 7) in order to ask them to explain such areas 
so that changes could be made for the benefit of the present and future generations of pre-service teachers. One could also investigate whether participants are still involved today in other extension projects, at their workplaces, especially for those who now work as supervisors ${ }^{5}$.

\section{Authors' contribution}

All authors participated in each stage of the work: together they designed and implemented the research, built the instruments, contacted the participants, and carried out the qualitative and quantitative analyses. Sonia Zyngier gave more input to the general essay and Sections 2 and 4. Gabriela Marques-Schäfer analyzed data from the questionnaire, drafted Section 4, and worked on the formatting, submission, and proofreading of the text. Danielle Menezes analyzed specific items of the questionnaire, drafted Section 3.1, wrote Sections 3.2 and 5 and contributed to other Sections. Alessandra Mitie Spallanzani analyzed part of the data and wrote Sections 3.3 and 5 . The introduction and conclusion were written by all authors collectively.

\section{References}

BRASIL. Constituição da República Federativa do Brasil. Brasília, DF: Senado Federal, 1988.

BRASIL. Lei de Diretrizes e Bases da Educaşão Nacional - Lei 9394/96. Brasília, DF: MEC/SEF, 1997.

BRASIL. Ministério da Educação. Diretrizes Curriculares Nacionais para os Cursos de Formação de Professores da Educação Básica, em nivel superior, curso de licenciatura, de graduação plena. Resolução CNE/CP 01/2002. Resolução CNE/CP 02/2002.

BRASIL. Ministério da Educação. Diretrizes Curriculares Nacionais para a formação inicial em nivel superior (cursos de licenciatura, cursos de formaşão pedagógica para graduados e cursos de segunda licenciatura) epara a formação continuada. Resolução CNE/CP 02/2015. BRASIL. Plano Nacional de Extensão Universitária. Brasília: 2009.

\footnotetext{
5 The last suggestion has been forwarded by anonymous reviewers, which we here acknowledge.
} 
CELANI, M. A. A. Considerações sobre a disciplina "Prática de Ensino de Inglês" nos Cursos de Licenciatura. In: . Ensino de Linguas. São Paulo: EDUC, 1984. p. $70-78$

FORPROEX - Política Nacional de Extensão Universitária. Manaus: Fórum de PróReitores de Extensão das Universidades Públicas Brasileiras, 2012. Available at: https://www2.ufmg.br/proex/content/download/452/2780/file/PNEU.pdf. Retrieved on: Dec. 06, 2018.

FREIRE, P. Extensão ou comunicação? 8. ed. Rio de Janeiro: Paz e Terra, 1983. (Coleção O Mundo, Hoje, 24).

FREIRE, P. Pedagogia da Autonomia. Rio de Janeiro: Paz e Terra, 1996.

FREIRE, P. Pedagogia do oprimido. Rio de Janeiro: Paz e Terra, 1970.

GIROUX, H. A. Os professores como intelectuais: rumo a uma pedagogia crítica da aprendizagem. Porto Alegre: Artes Médicas, 1997.

HOLEC, H. Autonomy in Foreign Language Learning. Oxford: Pergamon, 1981.

KINCHELOE, J. A formação do professor como compromisso político. Porto Alegre: Editora Artmed, 1997.

LIBERALI, F. C. O diário como ferramenta para a reflexão crítica. 1999. 179f. Tese (Doutorado) - Pontifícia Universidade Católica de São Paulo, Linguística Aplicada ao Ensino de Línguas, São Paulo, 1999.

LIBERALI, F. C.; ZYNGIER, S. Caderno de Reflexões. Rio de Janeiro: Serviço de Publicações da UFRJ, 2000.

LITTLE, D. Learner Autonomy. Definitions, Issues and Problems. Dublin: Authentik, 1991.

MARQUES, G. O.; SIMÕES, T. C. S.; RODRIGUES, A. C. F. O Projeto CLAC/ UFRJ e a formação de professores de alemão. In: FISCHER, Eliana, GLENK, Eva. MEIRELES, Selma (org.). Blickwechsel: Akten des XI Lateinamerikanischen Germanisitenkongresses. São Paulo: Edusp, 2005. v. 2., p. 230-248.

MEC/SEF. Base Nacional Comum Curricular. Brasília, 2016.

MEC/SEF. Conhecimentos de Línguas Estrangeiras. In: Orientações Curriculares para o Ensino Médio - Volume 1: Linguagens, Códigos e suas Tecnologias. Brasília: MEC/SEF, 2006.

MEC/SEF. Parâmetros curriculares nacionais: terceiro e quarto ciclos do Ensino Fundamental - Língua Estrangeira. Brasília: MEC/SEF, 1998. 
MENEZES, D. A. Ensino de inglês e formação de professores: reflexões sobre o contexto brasileiro. Educação \& Linguagem, São Bernardo do Campo, v. 18, n. 2, p. 101-119, Jul.-Dez. 2015. Doi: https://doi.org/10.15603/2176-1043/ el.v18n2p101-119. Available at: https://www.metodista.br/revistas/revistas-ims/ index.php/EL/article/view/6196/5217. Retrieved on: Jan. 04, 2019.

NICOLAIDES, C. S.; FERNANDES, V. Learner Autonomy in the light of Freire. D.E.L.T.A, São Paulo, v. 24: special issue, p. 493-511, 2008. Doi: https://doi. org/10.1590/S0102-44502008000300006. Available at: http://www.scielo.br/ scielo.php?script $=$ sci_arttext\&pid=S0102-44502008000300006. Retrieved on: Dec. 20, 2018.

PAULA, J. A. A extensão universitária: história, conceito e propostas. Interfaces Revista de Extensão da UFMG, Belo Horizonte, v. 1, n. 1, p. 5-23, jul./nov. 2013.

PÉREZ GÓMEZ, A. O pensamento prático do professor - A formação do professor como prático reflexivo. In: NÓVOA, A. (org.). Os professores e a sua formação. Lisboa: Dom Quixote, 1992. p. 93-114.

SMYTH, J. Teachers Work and the Politics of Reflection. American Educational Research Journal, [S.l.], v. 29, n. 2, p. 267-300, 1992. Doi: https://doi. org/10.3102/00028312029002268

SPALLANZANI, A. M. CLAC/UFRJ: influências e frutos de 1998 a 2018 para uma ex-participante do projeto, lecture notes. XV Fórum CLAC: Refletindo sobre o impacto e o futuro de um projeto de formação complementar de professores para o ensino de línguas. School of Letters of the Federal University of Rio de Janeiro, held on August 03, 2018.

UNIVERSIDADE FEDERAL DO RIO DE JANEIRO. Estatuto, Regimento Geral. Rio de Janeiro: UFRJ, 2018.

ZYNGIER, S.; LIBERALI, F. C. Pre-service teachers working with deprived communities in Brazil. In: AKKARI, A.; SULTANA, R.; GURTNER, Jean-Luc. (org.). Politiques et stratégies éducatives. Berna: Peter Lang, 2001b. v. 1, p. 275-284.

ZYNGIER, S.; LIBERALI, F. C. Teaching English to a Deprived Community: The Development of Critical Thinkers. Vertentes, São João Del-Rei, v. 1, n. 16, p. 20-30, 2001a. 


\section{ANNEX}

\section{THE QUESTIONNAIRE}

Projeto CLAC - Uma avaliação

Prezados/ Prezadas ex-monitores/ ex-monitoras do CLAC,

Estamos realizando uma pesquisa sobre o Projeto CLAC. Sua participação é muito importante para a pesquisa. Por favor, pedimos que reserve 15 minutos do seu tempo para preencher o seguinte questionário. Ao preencher e enviar, você nos autoriza a usar os dados para fins acadêmicos. Sua identidade será preservada. Muito obrigada pela participação. Se quiser saber mais sobre a pesquisa, entre em contato conosco.

Atenciosamente,

1. Você foi monitor do CLAC de qual língua?

( ) Inglês ( ) Francês ( ) Alemão ( ) Espanhol ( ) Japonês

( ) Italiano ( ) Português ( ) Hebraico

2. Por quantos semestres você atuou no Projeto?

( ) 1 semestre ( ) 2 semestres ( ) 3 a 4 semestres ( ) mais de 4 semestres

3. Você se especializou após a graduação?

( ) $\operatorname{sim}()$ não

4. Caso tenha respondido "sim" à questão anterior, por favor, indique sua maior titulação hoje.

( ) Especialização ( ) Mestrado ( ) Doutorado ( ) Pós-Doutorado ( ) Não

5. Caso tenha respondido à questão anterior, informe-nos se o CLAC influenciou suas escolhas na pós-graduação.

6. Onde você trabalha hoje?

7. O Projeto CLAC teve algum impacto na sua colocação profissional hoje?

8. O Projeto CLAC contribuiu para a sua formação como professor?

9. Há algo que mais se destaque positivamente no Projeto CLAC? O quê?

10. Você mudaria algo no Projeto CLAC? Se sim, o quê? 
11. Em uma escala de 1 a 5, na qual 1 é a nota mínima e 5 a máxima, qual nota você daria à contribuição que o Projeto CLAC pode ter tido no seu desenvolvimento profissional e pessoal com relação à sua/ ao seu...

- Capacidade de organização

nada importante $\quad \begin{array}{lllllll}0 & 1 & 2 & 3 & 4 & 5 & \text { muito importante }\end{array}$

- Senso de responsabilidade nada importante $\quad \begin{array}{lllllll}0 & 1 & 2 & 3 & 4 & 5 & \text { muito importante }\end{array}$

- Crescimento acadêmico nada importante $\quad \begin{array}{lllllll}0 & 1 & 2 & 3 & 4 & 5 & \text { muito importante }\end{array}$

- Relação com a sociedade/ comunidade nada importante $\quad \begin{array}{lllllll}0 & 1 & 2 & 3 & 4 & 5 & \text { muito importante }\end{array}$

- Relacionamento social com colegas, alunos e professores nada importante $\quad \begin{array}{lllllll}0 & 1 & 2 & 3 & 4 & 5 & \text { muito importante }\end{array}$

- Criticidade nada importante $\quad \begin{array}{lllllll}0 & 1 & 2 & 3 & 4 & 5 & \text { muito importante }\end{array}$

- Autonomia nada importante $\quad \begin{array}{lllllll}0 & 1 & 2 & 3 & 4 & 5 & \text { muito importante }\end{array}$

- Motivação para os estudos nada importante $\quad \begin{array}{lllllll}0 & 1 & 2 & 3 & 4 & 5 & \text { muito importante }\end{array}$

- Motivação para a carreira docente nada importante $\quad \begin{array}{lllllll}0 & 1 & 2 & 3 & 4 & 5 & \text { muito importante }\end{array}$

- Motivação para pesquisa acadêmica nada importante $\quad \begin{array}{lllllll}0 & 1 & 2 & 3 & 4 & 5 & \text { muito importante }\end{array}$

12. Nesse espaço, coloque 5 adjetivos que você usaria para qualificar o Projeto CLAC:

13. Por favor, relate aqui o que você gostaria de dizer sobre o Projeto e que não foi coberto pelas perguntas anteriores.

Data de submissão: 05/02/2019. Data de aprovação: 12/06/2019. 